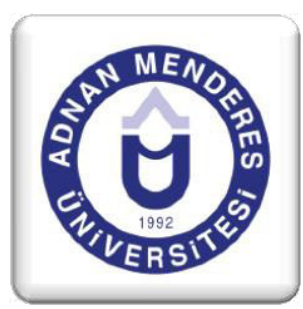

\title{
Büyükşehir Olma Sürecinde Bir Kent: Ordu
}

\section{The City in the Process of Becoming a Metropolitan: Ordu}

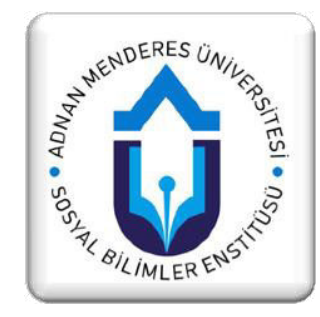

\section{Özet}

Kentler sürekli artan ihtiyaçlara cevap verebilmek için gelişen, değişen ve yaşayan oluşumlardır. Bu değişim ve gelişim süreci kentin kurulması ile başlar ve kent var oldukça artarak devam eder. Tüm bu değişim olumlu veya olumsuz sonuçlanabilirken, olumsuzluğu kentin göç vermesine, olumlu hali ise göç almasına neden olur. Kentin yaşadığı tüm bu farklılaşmalar kenti alansal, fiziksel, fonksiyonel, estetik beklentiler ve nüfus bazında değişimlere sürükler.

Ordu kenti doğası, denizi, yoğun kültürel etkinlikleri, havaalanı, üniversitesi, kentsel konumu, sakin yapısı ve ilçeleri ile Karadeniz Bölgesinin önemli ve yüksek gelişme potansiyeline sahip bir kentidir. Tüm bu özellikleri ile kent hızlı bir değişim süreci yaşamakta olup, 2013 yılı başında bu değişimin bir sonucu olarak Ordu, "Büyükşehir Belediyesi" statüsü kazanmış, merkez ilçe olarak da Altınordu ilçesi ve Belediyesi kurulmuştur. Bu çalışmada da hazırlık süreci hala devam etmekte olan kentin hali hazırdaki durumu, kentsel yapı ve şartları, imkan ve eksiklikleri, kentsel sorunları, büyükşehir olma süreci ve geleceğe dönük hedefler değerlendirilmiştir.

Anahtar kelimeler; Ordu, büyükşehir belediyesi, kent.

\section{Abstract}

Urban is a developing, living and changing formation to meet the needs of people in the urban. This changing and developing process starts when urban had set and continues with the urban. This changing process can be positive or negative for the urban. The urban gets immigration in the positive situation. This differentiations change urban as areal, physical, *Yrd. Doç. Dr. Ordu Üniversitesi Ziraat Fakültesi Peyzaj Mimarlı̆̆ functional, aesthetic and populaation.

Bölümü

Ordu City is an important urban of Blacksea Region with nature, sea, cultural activities, airport, university, location, tranquility and counties. The city is in a quickly developing process whit the properties. As a result of this developing The Ordu Municipality has changed as The Ordu Metropolitan Municipality in 2013.Altınordu was set as the centre county and the municipality. In this study was evaluated present situation, urban structure, condition, facility, deficiency, urban problems, preparation process for the metropolitan municipality and targets for future of the city that preparation process continues.

Keywords; Ordu City, metropolitan municipality, urban. 


\section{GİRIŞ}

Kent; ekonomisi tarım dışı faaliyetlere dayalı, toplumsal ilişkilerin ön planda bulunduğu, doğal ve kültürel öğelerle zaman içinde kendine has karakterini kazanmış, büyük ölçekli, uzun mesafe ve zaman aralığında algılanabilen bir mekân kurgusu (Güçlü,1993); sürekli toplumsal gelişme içinde bulunan ve toplumun yerleşme, barınma, gidiş-geliş, çalışma, dinlenme, eğlenme gibi gereksinimlerinin karşılandığ 1 , az sayıda kimsenin tarımsal uğraşılarda bulunduğu, köylere göre nüfus ve yapı sıklığı yönünden daha yoğun olan yerleşme birimidir (Keleş 1990). Buradan yola çıkarak, pek çok alanda, pek çok fonksiyon ile her yaştan, her cinsiyetten, her sosyal ve kültürel yapıdan kentliye hizmet veren böylesi kozmopolit bir oluşumun her şeyden bağımsız, gelişen ve değişen dünyadan, artan taleplerden, insanlardan etkilenmeden süregelmesi mümkün görülemez.

Kentler bir sistemler bütünü olup, pek çok fonksiyon ve mekandan meydana gelen ve bu mekanlar arasındaki ilişkiden teşekkül olan yaşayan oluşumlar, "idari olarak, yapılar ve diğer alanlarından oluşan çevre, siyasi olarak ortak amaçlar için, politik bilinçle bir araya gelmiş" (Altay vd. 2009) adına kentli denilen geniş topluluklar ile birlikte gelişen, değişen ve büyüyen canlı varlıklar olduğu için insanlar tarafindan kurulur ancak, kendi kendilerine yenilenirler. $\mathrm{Bu}$, bir ağaç tohumunun toprağa insan tarafindan ekilmesi ancak sonra ağacın büyümesinin ihtiyacı karşılandığı sürece doğal yollarla devam etmesi gibidir.

Nüfusa bağlı bir büyüme, ekonomik, sosyal ve kültürel yapıda sürekli bir değişim ve devingenlik, aynı zamanda kentin fiziksel alanının, sınırlarının sürekli büyümesi (Aydemir 1999) olan kentleşme doğduktan sonra varlığını devam ettirmesinin temel nedeni ve yapı taşı olan insanoğlunun sürekli çeşitlenen ve değişen talep, beklenti ve isteklerini karşılayabilme çabası ve sürecinin bir ürünüdür. Tüm bunlara uyum sağlamaya çalışıp, kentlinin ihtiyaçlarına ve çağın gereklerine yetişebilme çabası içerisinde kent tek başına karar verici değildir. Kent, tüm bu değişim süreci içerisinde, kendisini oluşturan toplumun tarihi geçmişi ve kültüründen etkilenir ve hatta yönlenir. Kentlerin kuruluş amaçlarının ve kuruldukları yerlerin ekonomi, güvenlik, ulaşım, coğrafi koşullar gibi pek çok nedenleri vardır.

Bireyler, ister bulundukları yerde, ister gittikleri kentte kendi kültür, inanç ve yaşam anlayışlarını da beraberlerinde götürür ve yaşatırlar. İnsanlığın doğası ve temel ihtiyacı olan bu özelliği kentlerin oluşmasında, değişiminde, yani dünü, bugünü ve geleceğinde en etkin faktördür. Bu faktör, dünyanın her yerinden farklı kültürlerin farklı karakterlerde, farklı imajlarda, farklı ihtiyaçları karşılayan kentleri oluşturmasına neden olmuştur. Böylece her medeniyet kendi kültür ve inançları, kendi doğruları, hayat anlayışları, yaşam tarzları, sosyal yapıları, gelenek ve adetlerine, atalarından ve tarihlerinden kendilerine kalan miraslar üzerine temellendirdikleri prensipler ile kendi kentlerini kurmuşlar veya gittikleri yerleri bu anlayışlarına göre şekillendirmişlerdir. Bu nedenle de kültürden kaynaklanan etkilerle kentler fonksiyon ve estetik yönünden mimari, planlama ve tasarım açısından farklılıklar göstermiş, mimari akım ve şehircilik stilleri de bu ihtiyaçlara binaen ortaya çıkmıştır (Atabeyoğlu vd. 2010).

İnsanlar toplu yaşamaya başlamalarından sonra çevre ile olan ilişkilerinde daha etkili olmaya başlamışlardır. Toplum büyüdükçe sorunları gelişmiş ve değişmiştir. Günümüz toplumlarında sosyoekonomik, psikolojik, politik ve fizik mekan sorunları ağırlık kazanmıştır. Bu sorunların çözümlenmesi ve toplum yaşamının doğa ile dengeli olması için teknik olanaklar gereklidir ve tekniğin gelişmesi ise ekonomiye bağımlıdır. Planlama yapılması için ise, teknik ve ekonomik olanakların bütünleşmesi gerekmektedir (Ergen 1981).

Çeşitlenen ihtiyaçlar, bilim, teknoloji, kent kültürü, artan eğitim seviyesi, sürekli güncellenen yapılaşma imkanları içerisinde ve zamana ayak uydurma çabası kent sistemleri ve mimariyi etkileyerek kentin de değişimini tetikler. Buna en iyi ayak uydurabilen kentler de ise hızlı nüfus hareketlerine bağlı olarak büyük bir kalabalıklaşma, aksi durumlarda ise nüfusta azalma meydana gelir. $\mathrm{Bu}$ da kentin ekonomik gücü ve yapısını tetikleyerek kentin fonksiyonel ve estetik ihtiyaçları karşılama yönünde ya destek sağlar, yada sorunlar yaşamasına neden olur. Ekstra barınma ve istihdam ihtiyacı gibi gerekler ise kenti büyüyüp, genişlemeye zorlar. Bu da bir noktadan sonra kentin sorunlar yaşaması için ortam hazırlamaya başlar. 
Adnan Menderes University, Journal of Institute of Social Sciences, Vol.: 1, Special Issue

Altay vd. (2009)'a göre eğer kentler planlı ve sistemli şekilde değişimlere hazırlıklı kılınmazsa;

- Kentsel fiziksel çevrenin bozulması

- Nüfus yoğunlaşması ve yoksullaşma

- Tarihi dokunun yok olmas1

- Düzensiz ve çarpık büyüme

- Kentsel hizmetlerin yetersiz hale gelmesi

- Aşırı trafik yükü

- Ses, hava ve toprak kirliliği

- Kentsel yaşamın kalitesizleşmesi

- Satın alınabilir kaliteli konut sıkıntısı

- Sosyal sorunlar ve sağlik problemleri

- Kuşak çatışmaları

- Sosyal gruplar arası farklılıklar ve hoşgörü eksikliği

- Özellikle gençler arasında yüksek işsizlik

- Birbirine yabancılaşmış çevreler

- İşsizlik, zararlı alışkanlıklar ve barınma sorunlarına bağlı suç ve şiddet içeren ilişkilerin yaygınlaşması gibi olumsuz sonuçlar ve süreçlerle karşı karşıya kalırlar.

Kentler de parçası oldukları dünyaya ve insanlara uyum sağlamak zorundadırlar. Bu nedenle de bir kente yönelik planlama ve tasarım süreci asla sona ermez. Artan nüfusa, modern çağın gereklerine, alansal büyüme ve benzeri ihtiyaçlara cevap verebilmek için sürekli yeni tasarımlar ve planlar üretilmelidir. Plan ve tasarımcılar da buna bağlı olarak sürekli yeni şeyler üretmek ve bunun için de kendilerini yenilemek ve geliştirmek zorundadırlar. Sürekli değişim gösteren gereksinimlere cevap verebilmek ve ilerleyen çağa uyum sağlayabilmek ise farklı meslek disiplinlerinden pek çok uzman ile tasarımcı ve planlamacıların ortak çalışması ile mümkün olabilir. Bu süreç yerel yönetimler, kurumlar, idari mekanizmalar ve kent sakinleri ile birlikte gerçekleşir. İhtiyaçların, gereklerin, doğru işletim yöntemlerinin, kent olanaklarının, kentin doğal ve kültürel potansiyellerinin doğru teşhisi ile kente ilişkin çok boyutlu doğru kurgunun oluşturulması kentin her boyutuyla sistemli işlemesine, sağlıklı bir yapı kazanmasına, istikrar ve sürekliliğine katkı sağlar. Kentler alansal olarak genişleyip, sorumlu olduğu nüfus arttıkça sağlıklı ve sürdürülebilir kentleşme zorunluluğu kendini daha çok hissettirir ve yerel yönetimler üzerinde de o denli baskı kurarak bir etki mekanizmasına dönüşür.

Türkiye hızla gelişen, değişen, nüfusu hızlı artan, enerjisi yüksek, genç ve dinamik ülke olup, bu dinamizm kendisini tek tek her bir il bazında da hissettirmektedir. İlerleyen zamana ve gelişen çağın gereklerine ayak uydurma çabasındaki diğer iller gibi, Ordu da bu değişim sürecinden etkilenen ve kendisini geliştiren bir ildir. Özellikle son yıllarda ivme kazanan, sakin, huzurlu, gelişmiş ve modern yapısına nazaran küçük bir Karadeniz şehri olan Ordu, sahip olduğu çok çeşitli ve yükssek potansiyeli ile dikkat çekmektedir. $\mathrm{Bu}$ değişim il bütününde kentsel fonksiyonlar, göç ile nüfus artışı, turizm hareketleri, fiziki alan, kültürel, sosyal, ekonomik kent yapısı, kentlilik bilinci ve yaşam tarzı gibi pek çok olguya yansıyarak kent üzerine önemli etkiler sağlamaktadır. 


\section{GENEL ÖZELLIKLERIYYLE ORDU KENTI}

Ordu, 1920 yılına kadar Trabzon'a bağlı bir ilçedir. 1920 yılında il olmuş ve aynı tarihte Fatsa da bu ile bağlanmıştır. Karadeniz Bölgesi Doğu Karadeniz bölümünde yer alan Ordu İli Canik Dağları ile Karadeniz arasında dar bir alanda küçük bir körfezde kurulmuştur. Karadeniz'e kıyıs1 96,56 km uzunluğunda olan ilde, deniz araçlarının kolaylıkla barınabilecekleri küçük koy ve körfezler bulunmaktadır. Toplam yüzölçümü 5961 km²'dir (Ordu Valiliği İl Çevre ve Orman Müdürlüğü, 2004). (Şekil 1).

Kent 1940 yılına kadar oldukça hızlı bir şekilde göç vermiş, 1970'lere kadar Türkiye nüfus artış hızından bile daha yüksek bir hızla göç almıştır. Kent nüfusunun 1930'lardan 1960'lara kadar dalgalanma gösterdiği görülmektedir. Kentte göç hızı da 1975-2013 yılları arasında dalgalanma göstermiş ve eksi yönde olmuştur. Kentin 2011-2012 yıllarında pozitif göç değeri gösterdiği görülmektedir (Çizelge 1). Adrese dayalı sistem, 2012 yılı TUIKK verilerine göre Ordu il nüfusu büyüklügü olarak 741371 değeri ile Türkiye genelinde 30 . sırada yer almaktadır. 2012 verileri ile il ve ilçe merkezleri, belde ve köy nüfusunun toplam nüfus içindeki oran1 \%57,10'dur. Ordu ili nüfus yoğunluğu açısından (125) Türkiye ortalamasından (98) büyük değere sahiptir. Nüfus artış hızı binde 37,07 değeri ile binde 12,01 olan Türkiye değerinin üstündedir. İl binde 29,63 ile göç alan iller arasındadır. Yıllık ortalama artış hızı (\%o) 1,5'tir. 2012 yılı itibariyle Ordu'da 104 milyon dolar ithalat, 334 milyon dolar ihracat yapılmıştır. Ordu ili 2012 yılı bitkisel üretim değeri açısından 919milyon TL ile 34. sirada, canlı hayvanlar değeri bakımından 558 milyon TL ile 49. sirada gelmektedir. İlde işsizlik \%5,4 değeri ile \%7,9'luk Türkiye değerinin altındadır (TUİK, 2014).

Çizelge 1. Dönemlere Göre Ordu İli Göç Verileri (TUIKK, 2014)

\begin{tabular}{lcccccr} 
Dönem & Toplam nüfus & Aldığı göç & Verdiği göç & Net göç & Net göç hızı(\%o) & $\begin{array}{c}\text { Yıllık nüfus } \\
\text { artış hızı (\%o) }\end{array}$ \\
\hline $\mathbf{1 9 7 5 - 1 9 8 0}$ & 629167 & 19081 & 39749 & -20668 & -32.3 & - \\
\hline $\mathbf{1 9 8 0 - 1 9 8 5}$ & 689804 & 20916 & 45146 & -24230 & -34.5 & - \\
\hline $\mathbf{1 9 8 5 - 1 9 9 0}$ & 764782 & 28124 & 71034 & -42910 & -54.6 & - \\
\hline $\mathbf{1 9 9 5 - 2 0 0 0}$ & 809013 & 35790 & 72748 & -36958 & -44.7 & -5.4 \\
\hline $\mathbf{2 0 0 7 - 2 0 0 8}$ & 719278 & 27719 & 31458 & -3739 & -5.2 & 5.9 \\
\hline $\mathbf{2 0 0 8 - 2 0 0 9}$ & 723507 & 30335 & 31296 & -961 & -1.3 & -6.0 \\
\hline $\mathbf{2 0 0 9 - 2 0 1 0}$ & 719183 & 27896 & 36241 & -8345 & -14.5 & -6.7 \\
\hline $\mathbf{2 0 1 0 - 2 0 1 1}$ & 714390 & 23963 & 34472 & -10509 & 29.6 & -1.6 \\
\hline $\mathbf{2 0 1 1 - 2 0 1 2}$ & 741371 & 48240 & 26595 & 21645 & $-15,540$ & -13.5
\end{tabular}

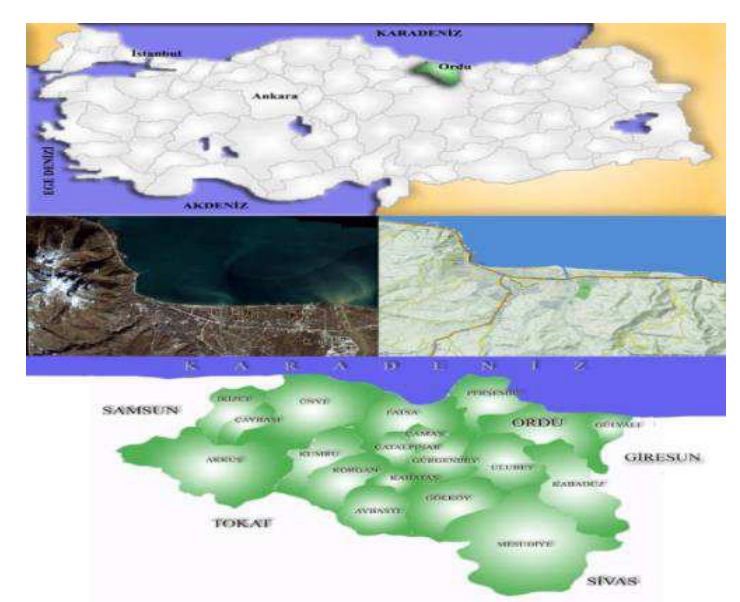

Şekil 1.Ordu kenti komşuluk, ulaşım haritası ve uydu görüntüsü (Google Map, 2007) 
Kent göç almaktan ziyade göç veren bir karaktere sahiptir. 2000'lere kadar oldukça yüksek seyreden ve 35000 kişinin üzerine çıkan dişarı göç, son yıllarda azalmış, hatta 2011 yılında pozitif göçe geçmiş olmasına rağmen düşüş trendi 2012 yılında da devam etmiştir. Bu negatif göçün sebebi findık yetiştiriciliğinin geçmişteki ekonomik getiriyi sağlamamasının yanı sıra sanayi imkanlarının da kentte gelişmemiş olması sonucu okuyan ve maddi kaynaklarını değerlendirmek isteyen kesimin şehirden ayrılmasıdır. Bununla paralel olarak yurt içi göçlerin dışında, Ordu'dan yurt dışına göç etmiş Orduluların da sayısı son derece fazladır. Gerçekleştirilen nüfus projeksiyonlarına göre kent önümüzdeki 10 yıllık süreçte de dalgalı bir nüfus yapısına sahip olacak ve nüfusu bugüne oranla 2023 yılında büyük farkl1lık göstermeyecektir (Çizelge 2).

Çizelge 2. Y1llara Göre Nüfus Projeksiyonu (TUİK, 2014)

\begin{tabular}{lllllllllll}
\hline \multicolumn{10}{c}{ Nüfus Projeksiyonu } \\
\hline $\mathbf{2 0 1 3}$ & $\mathbf{2 0 1 4}$ & $\mathbf{2 0 1 5}$ & $\mathbf{2 0 1 6}$ & $\mathbf{2 0 1 7}$ & $\mathbf{2 0 1 8}$ & $\mathbf{2 0 1 9}$ & $\mathbf{2 0 2 0}$ & $\mathbf{2 0 2 1}$ & $\mathbf{2 0 2 2}$ & $\mathbf{2 0 2 3}$ \\
\hline 744444 & 747104 & 749348 & 751180 & 752614 & 753669 & 754352 & 754655 & 754577 & 754163 & 753396
\end{tabular}

Ordu İline bağlı biri merkez ilçe Altınordu olmak üzere 19 ilçe bulunmaktadır. 2013 Yılı TUIKK verilerine göre büyükşsehir kapsamı içerisinde yer alan 19 ilçe arasında en yüksek nüfusa sahip olanlar 186.000 ile Altınordu, 117,995 ile Ünye ve 107.031 ile Fatsa'dır. Yüksek nüfuslarının yanı sıra kentsel fonksiyonlar ve imkanlar açısından da bunlar ilin diğer ilçelerine göre daha gelişmiş ilçelerdir (Çizelge 3). İlin en düşük nüfusa sahip olan ilçesi ise kente en yakın, hatta kente bitişik olan ve havaalanına da ev sahipliği yapan Gülyalı İlçesidir.

Perşembe İlçesi Türkiye'deki 9 Sakin Şehir (Cittaslow)'den birisidir. Cittaslow, 1999 Yılında İtalya'da kurulmuş olan uluslararası bir belediyeler birliğidir. 28 Ülkeden 182 belediyenin üyesi olduğu organizasyona çeşitli kentsel olgulardan 70 adet kriteri sağlayan şehirler kabul edilmektedir. Türkiye'deki diğer Sakin Şehirler Akkaya/Muğla, Gökçeada/Çanakkale, Seferihisar/İzmir, Taraklı/Sakarya, Yenipazar/Aydın, Yalvaç/Isparta, Vize/Kırklareli, Halfeti/Şanlıurfa olup, Ordu'nun Perşembe İlçesi 2012 yılında dünyadaki 161. Sakin Şehir olarak ilan edilmiştir.

Çizelge 3.İlçelere Göre Nüfus Bilgileri, 2013(TUİK, 2014).

\begin{tabular}{llll} 
İlçe & Nüfus Bilgisi & İçe & Nüfus Bilgisi \\
\hline Akkuş & 31.106 & Kabadüz & 8.670 \\
\hline Aybastı & 24.852 & Kabataş & 12.417 \\
\hline Çamaş & 9.381 & Korgan & 33.000 \\
\hline Çatalpınar & 14.695 & Kumru & 31.847 \\
\hline Çaybaşı & 15.295 & Merkez-Altınordu & 186.000 \\
\hline Fatsa & 107.031 & Mesudiye & 18.805 \\
\hline Gölköy & 37.564 & Perşembe & 32.150 \\
\hline Gülyalı & 7.957 & Ulubey & 16.999
\end{tabular}




\begin{tabular}{llll} 
Gürgentepe & 15.275 & Ünye & 117.995 \\
\hline İkizce & 20.332 & &
\end{tabular}

Ordu kentinin 1927 yılında 113.004 olan kent nüfusu 1945 yılında en az düzeyine gerileyerek 78.820 olmuştur. Bu tarihten itibaren yeniden göç alan kent 2008 yllında 167.829 'a, 2013 yllında ise 186.000 'e ulaşmıştır (Çizelge 5). Kentin köyler dahil 167.829 olan nüfusunun 33.824'ünü köyler, 134.005'ini de şehir nüfusu oluşturmaktadır (Çizelge 6). Kentin ortalama nüfus artış hızı \%12'dir. Kentte, mücavir alan sınırları içerisinde nüfusları 482 ile 16.947 kişi arasında değişim gösteren 26 adet mahalle bulunmaktadır (Şekil 2). 482 kişi ile Akçatepe mahallesinin en az nüfusa, Yeni mahallenin de 16.947 ile en fazla nüfusa sahip mahalleler olduğu ortaya çıkmaktadır.

Çizelge 5. 1927-2013 Tarihleri Arası Ordu Kent Nüfusu (Ordu Valiliği İl Çevre ve Orman Müdürlüğü, 2004) (TUIKK)

\begin{tabular}{llllllllll} 
Yıl & $\mathbf{1 9 2 7}$ & $\mathbf{1 9 3 5}$ & $\mathbf{1 9 4 0}$ & $\mathbf{1 9 4 5}$ & $\mathbf{1 9 5 0}$ & $\mathbf{1 9 5 5}$ & $\mathbf{1 9 6 0}$ & $\mathbf{1 9 6 5}$ & \\
\hline Nüfus & 113.004 & 146.180 & 97.892 & 78.820 & 88.557 & 95.804 & 85.363 & 100.996 & \\
\hline Yıl & $\mathbf{1 9 7 0}$ & $\mathbf{1 9 7 5}$ & $\mathbf{1 9 8 0}$ & $\mathbf{1 9 8 5}$ & $\mathbf{1 9 9 0}$ & $\mathbf{1 9 9 5}$ & $\mathbf{2 0 0 0}$ & $\mathbf{2 0 0 8}$ & $\mathbf{2 0 1 3}$ \\
\hline Nüfus & 115.787 & 125.703 & 132.950 & 151.361 & 142.075 & 155.925 & 150.586 & 167.829 & 186.000
\end{tabular}

Çizelge 6. Ordu Mücavir Alan Sınırları İçerisindeki Mahallelerin Mevcut Nüfusları (Ordu Valiliği İl Çevre ve Orman Müdürlüğü,2004)

\begin{tabular}{llllll} 
& \multicolumn{5}{c}{ Nüfus (\%12 artış) } \\
\cline { 2 - 6 } Mahalleler & $\mathbf{2 0 0 0}$ yılı & $\mathbf{2 0 0 8}$ yılı & Mahalleler & $\mathbf{2 0 0 0}$ yılı & $\mathbf{2 0 0 8}$ yılı \\
\hline Kumbaşı & 1.620 & 1.905 & Subaşı & 7.447 & 8.432 \\
\hline Güzelyalı & 1.874 & 2.190 & Yeni & 15.050 & 16.947 \\
\hline Kirazlimanı & 1.095 & 1.317 & Şirinevler & 5.840 & 6.632 \\
\hline Taşbaşı & 2.072 & 2.412 & Bahçelievler & 4.731 & 5.390 \\
\hline Zaferimilli & 1.953 & 2.278 & Akyazı & 11.451 & 12.916 \\
\hline Aziziye & 1.588 & 1.870 & Karacaömer & 1.849 & 2.162 \\
\hline Saray & 1.609 & 1.893 & Eskipazar & 696 & 871 \\
\hline Düz & 2.388 & 2.766 & Karşıyaka & 8.567 & 9.686 \\
\hline Selimiye & 8.580 & 9.701 & Karapınar & 1.396 & 1.655 \\
\hline Şarkiye & 7.081 & 8.022 & Durugöl & 2.865 & 3.300 \\
\hline Nizamettin & 2.361 & 2.735 & Cumhuriyet & 4.457 & 5.083 \\
\hline Bucak & 14.601 & 16.444 & Akçatepe & 349 & 482 \\
\hline Şahincili & 3.780 & 4.325 & Turnasuyu & 2.230 & 2.589 \\
\hline & & TOPLAM & $\mathbf{1 1 7 . 5 3 0}$ & $\mathbf{1 3 4 . 0 0 5}$ \\
\hline & & & Merkez Köyler & 33.824 \\
\hline & & & $\mathbf{T O P L A M}$ & $\mathbf{1 6 7 . 8 2 9}$ \\
\hline
\end{tabular}




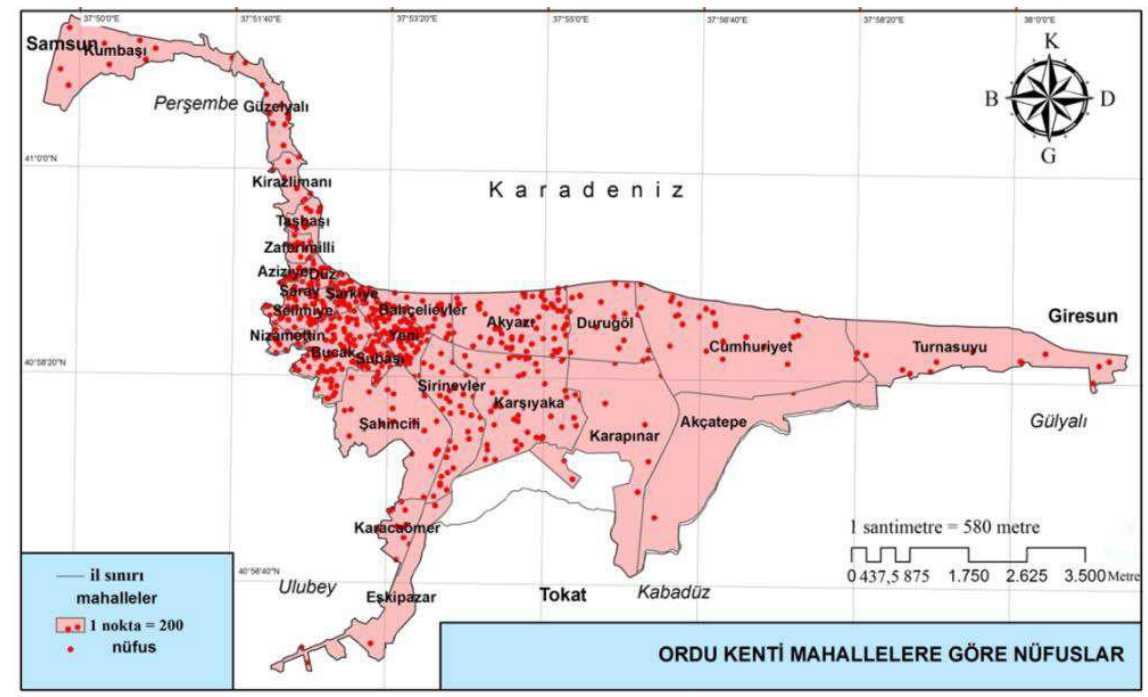

Şekil 2. Mahalle bazlı nüfus yoğunluğu haritası

\subsection{KENTSEL KORUNAN ALANLAR}

Kent sınırları içerisinde pek çok koruma alanı mevcut olup, bunları kentsel sit alanları, 1. ve 2. derece arkeolojik sit alanları ve çok sayıdaki anıt oluşturmaktadır. Kentte birisi ilçede olmak üzere 2 adet kentsel sit, kent merkezinde ve çeşitli ilçelerde olmak üzere 10 tanesi 1. derece, 4 tanesi de 2. derece arkeolojik sit alanı, 25 adet de anıt bulunmaktadır. Kentteki anıtları hamamlar, camiler, çeşmeler, kiliseler, kaya mezarları ve şadırvanlar meydana getirmektedir. Ordu ilinde 5 adet doğal sit alanı, 5 adet de doğal miras alanı bulunmaktadır (Çevre ve Orman Bakanlığı, 2006).

Kentte tarihi yapılar Taşbaşı, Zaferimilli, Aziziye, Saray, Düz, Selimiye ve Şarkiye mahallelerinde bulunmaktadır (Şekil 4.94). Kentin tarihi çekirdeği de zaten bu mahallelerin bulunduğu yerdir. Mücavir alan sınırları içerisinde bir adet tarihi sit alanı bulunmaktadır. Sit alanı Taşbaşı, Zaferimilli ve Aziziye mahallesinde bulunmaktadır. Ancak kentte sit alanı dışında da tescilli yapılar bulunmaktadır. Toplam tescilli yap1 sayıs1 143 olup, bunların 131 adedi sivil mimarlık örneği, 12'si de tescilli anıt eser kategorisindedir. Bunların 94 adedi sit alanı içerisinde 49 adedi de sit alanı dışındadır (Şekil 3).

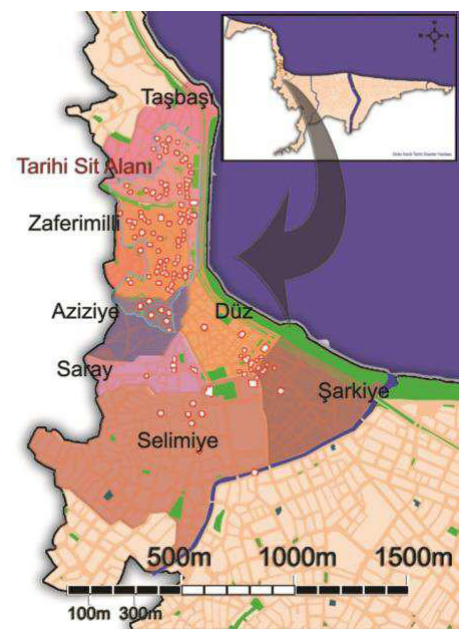

Şekil 3. Tarihi yerleşime ilişkin harita 


\subsection{SOSYO-KÜLTÜREL DURUM}

İl merkezinde; 1 kültür merkezi, 1 konservatuar, 2 tiyatro, 2 sinema bulunmaktadır. Ayrıca özellikle kıy1 bandında çok sayıda restoran ve kafe bulunmaktadır. Halk Eğitim, üniversite, çeşitli kurumlar ve dernekler aracılığıyla pek çok alanda kurslar yapılmaktadır. 1 adet il halk kütüphanesi ve 1 de müze mevcuttur. Kentin çeşitli yerlerindeki kapalı spor salonu, açık spor sahaları, olimpik yüzme havuzu ve spor merkezleri ile spor faaliyetleri konusunda da imkanlara sahiptir.

\subsection{SOSYO-EKONOMIK DURUM}

Ordu İli genelde küçük ve orta boy işletmelerden müteşekkildir. En önemli sektör gıdadır (\%66). Gıda sektörü içinde de en büyük grup findık kırma ve işleme tesislerinindir. Ordu İli sanayi gurupları \%53 gıda, $\% 11$ toprağa dayalı sanayi, $\% 9$ tekstil, $\% 8$ orman, $\% 5$ metal, $\% 1$ madencilik, $\% 1$ kimya ve $\% 12$ de diğer sanayi kollarından ibarettir. İlde tüm sanayi gurupları bazında toplam sanayi kuruluşu sayısı 123 'ü merkez ilçede olmak üzere 249 'dur. İl Merkezinde 1 adet sunta fabrikası, 2 adet un fabrikası, 1 adet de yağlı tohum ve ürünlerden sıvı yağ çıkartan fabrika vardır. Ayrıca findığı işleyen gıda sanayi, 20 civarında findık kırma fabrikası ve 1 adet findık kavurma fabrikası vardır (Ordu Valiliği Çevre ve Şehircilik Müdürlügü̈,2011).

\subsection{KENTSEL GENIŞLEME}

Ordu Kenti yoğun şekilde kıyı boyunca yayılım göstermekte olup, doğuda Giresun, batıda Samsun yönünde ilerlemektedir. Kıyı boyunca dizilen ilçeleri de nispeten daha hızlı gelişim gösteren ve yoğun nüfuslu ilçeleridir. Mevcut ve ileriye dönük yatırım ve planlar da özellikle kıyı hattı boyunca kendini göstermektedir. Karayolunun kıyı boyunca geçiyor oluşu da bu büyümeyi destekleyen önemli bir etkendir.

Samsun-Giresun karayolu boyunca konut ve turizm sahası olarak gelişen kent, karayolu boyunca gelişmektedir. Cumhuriyet Mahallesi Ordu-Ulubey yolu üzerindeki alanlarda ve sahilde Efirli Bölgesinde de kent dokusuna ilave modern gelişme alanları oluşmuştur. Ordu'nun ilk kuruluş yeri Boztepe'nin doğuya bakan yamaçlarıdır. Buralardaki yerleşmeler Ordu'nun en eski mahalleleridir. Mahalleler eğimli bir alanda kurulduğu için manzara ve güneşten olabildiğince yararlanmaktadırlar. Bugün ise kent Cumhuriyet Mahallesi yönüne doğru gelişimini sürdürürken, TOKİ'nin seçiminin kentin güneyinde olması, kentin gelişiminin bir kısmının bu yöne doğru kaymasında etkili olmaktadır (Ordu Valiliği Çevre ve Şehircilik Müdürlüğü,2011).

\subsection{KENT DOĞASI}

Kentte batıdan doğuya doğru dört farklı akarsu geçmektedir. Bunlar yine batıdan doğuya doğru sırasıyla Melet Irmağı, Civil Irmağı, Bülbül Deresi ve Turna Deresidir. Kentte hakim rüzgar yönü batı-doğu yönündedir. Kent kuzeyden denizle sınırlanmakta olup, kıyı uzunluğu 20.033m'dir. Kent, doğu, batı ve güneyden ise ormanlık alanlarla kaplı tepelerce çevrelenmiştir. Bu nedenle kentin hem güney, doğu ve batı yönlerinde orman manzarası, hem de kuzey yönünde deniz manzarası mevcuttur. Kent genelinde yükseklik farkı fazla olmayıp, kentin büyük kısmı nispeten düz bir alana yerleşmiştir. Kentin odak noktaları ve cazibe merkezlerinden en önemlisi kentin batısında ve kenti yukarıdan panoramik olarak izleyen, tepenin üzerine kurulu Boztepe'dir. Bunun dişında kamu kurumlarının yoğunlaştığ ve kentin merkezi konumundaki Taşbaşı, Düz, Şarkiye ve Bahçelievler Mahallelerini içine alan bölge ve özellikle suya dayalı rekreasyonel faaliyetlerin gerçekleştiği Cumhuriyet ve Turnasuyu Mahalleleri kapsamındaki plaj kesimi kentin öncelikli odak ve çekim merkezleridir. Kentleşme çalışmalarına özellikle önem arz eden, rekreasyonel faaliyetlere merkez olabilecek nitelikte, kentin prestijine, gelişimine ve kimliğine katkı sağlayacak önemli kaynak değerleri kent içinden geçen akarsulardır.

\subsection{KENTSEL YEŞİL ALANLAR}

Çevresi ormanlık alanlar ve fındık bahçeleriyle çevrili olan Ordu kenti mücavir alan sınırları içerisinde imar planları üzerinden gerçekleştirilen çalışmalara göre kentte 21 adet spor alanı mevcuttur. Bu tesisler Selimiye, Eskipazar, Karşıyaka, Karapınar, Cumhuriyet, Akçatepe ve Turnasuyu Mahallelerinde bulunmaktadır. En geniş spor alanları Cumhuriyet ve Eskipazar mahallelerinde yer almaktadır. Özellikle Zaferimilli, Aziziye, Saray, Selimiye, Nizamettin ve Subaşı mahalleleri yeşil alanlar bakımından özellikle 
Adnan Menderes University, Journal of Institute of Social Sciences, Vol.: 1, Special Issue

yetersizlik yaşayan mahallelerdir. Zaferimilli ve aziziye mahalleleri özellikle yoğun konut dokusu ve tarihi yapıları ile Saray, Selimiye, Nizamettin ve Subaşı ise yoğun konutlaşma ile dikkat çekmektedir (Şekil 4).

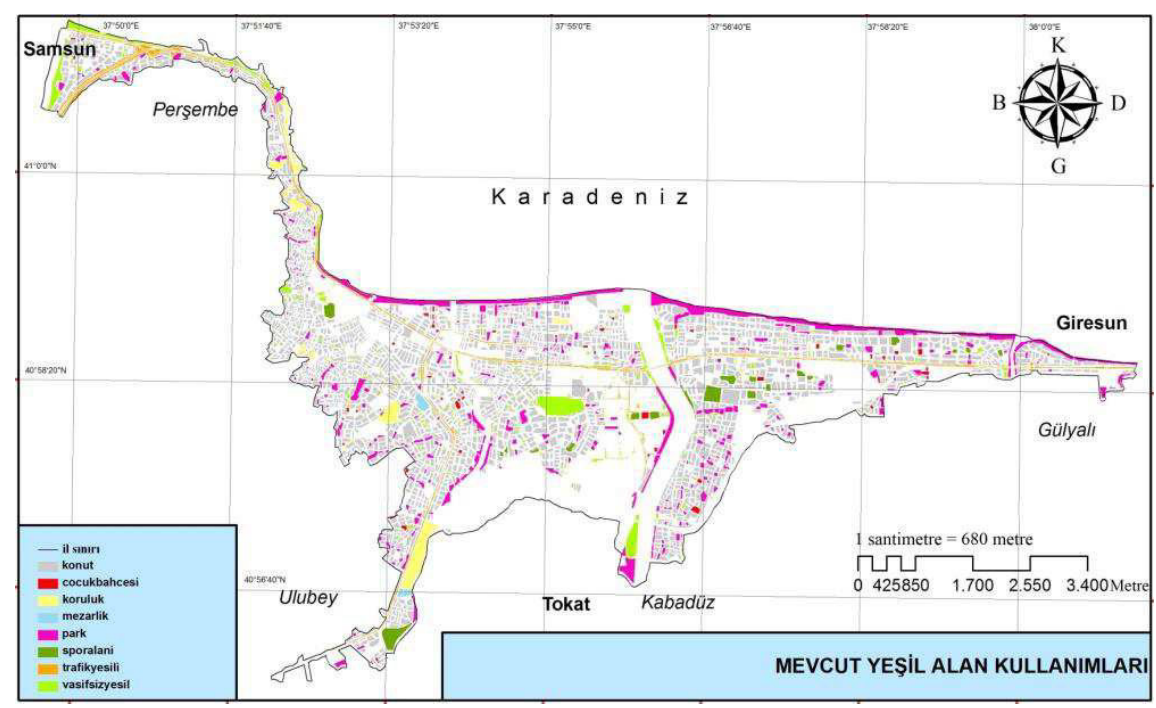

Şekil 4. Mevcut yeşil alan kullanımları haritası

İmar planı üzerinden CBS (Coğrafi Bilgi Sistemleri) ile gerçekleştirilen çalışmada kent mücavir alan sınırları içerisinde 2424 adet konut parseli olduğu tespit edilmiştir. En geniş miktarda konut alanına sahip mahalle Cumhuriyet Mahallesidir. Bunu sırasıyla Akçatepe ve Şahincili takip etmektedir. En az konut yerleşimi ise Düz Mahallede bulunmakta olup, Şarkiye Mahallesinde ise konut yerleşimi olmadığı tespit edilmiştir. Konut yerleşimleri, imar planlarında konut olarak yapılaşma izni verilmiş ve konutlara ait bahçeleri de kapsayan alanlar olarak değerlendirilmiştir (Şekil 5).

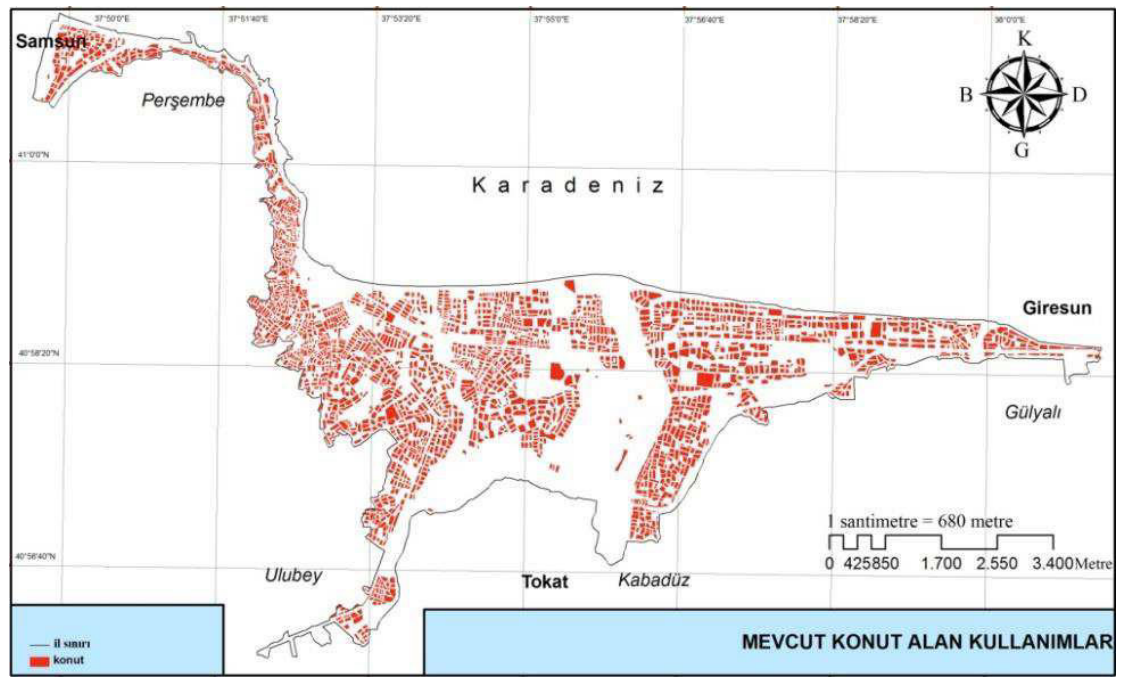

Şekil 5. Mevcut konut alanları haritası

Kent İçinde ticari tesisler Karapınar Mahallesinde sanayi tesisleri şeklinde yoğunlaşmıştır. Kentin diğer kesimlerinde de yine sanayi tesisleri bulunmasına karşılık Karapınar'daki kadar büyük yoğunluk 
Adnan Menderes University, Journal of Institute of Social Sciences, Vol.: 1, Special Issue

göstermemektedir. Bu anlamda en büyük yoğunlaşmanın görüldüğü mahalleler Cumhuriyet ve Eskipazar mahalleleridir. Bu ticari tesislerin büyük oranda yoğunlaştığı yerler özellikle kent merkezi ve çevresi olarak göze çarpmaktadır (Şekil 6).

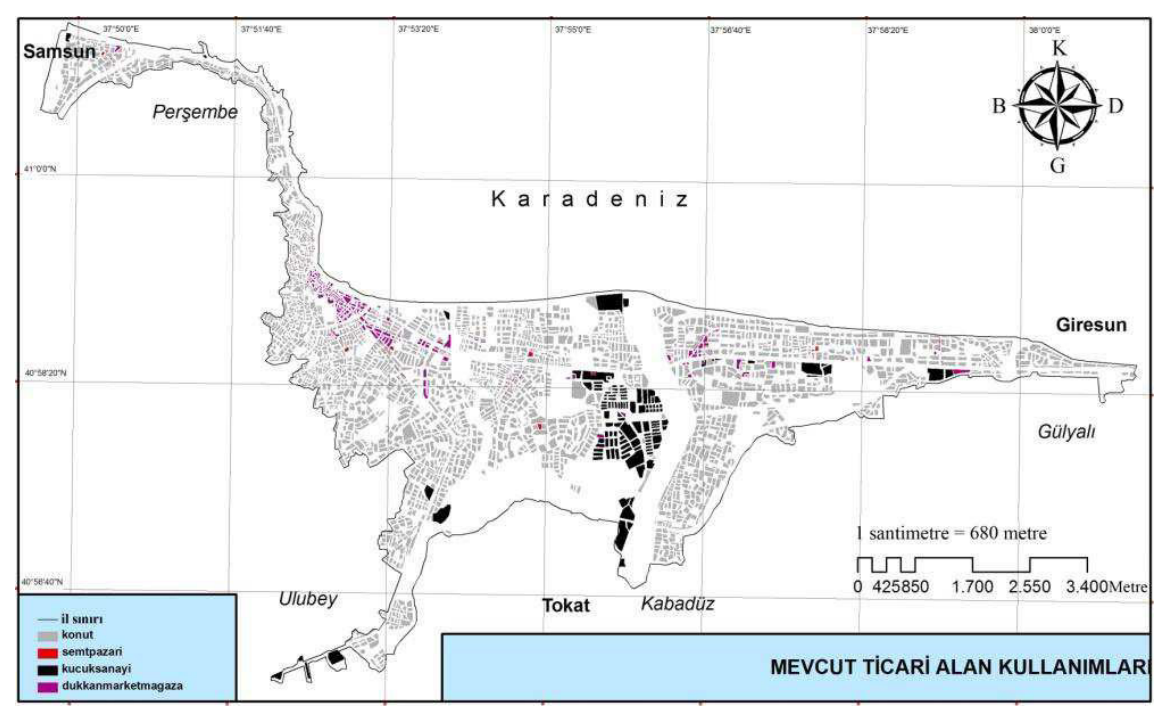

Şekil 6. Mevcut ticari alan kullanımları haritası

Kentte, imar planı verilerine göre mücavir alan sınırları içinde 56 adet kurum bulunmaktadır. En çok sayıda kurumsal alan Saray, Düz ve Şarkiye Mahallelerinde göze çarpmakta iken, kurumsal alanlar anlamında ve bahçe alanları da dahil olacak şekilde en geniş yayılımlar Eskipazar, Karşıyaka, Akyazı ve Durugöl Mahallelerindedir. Bunlarında dışında daha pek çok mahallede kurumsal alanlar mevcut olmakla birlikte küçük yayılımlı ve sayıca azdır. Güzelyalı, Kirazlimanı, Taşbaşı, Zaferimilli, Aziziye, Nizamettin, Şahincili, Subaşı ve Yeni Mahallelerde de hiç kurumsal alanlara rastlanmamaktadır (Şekil 7).

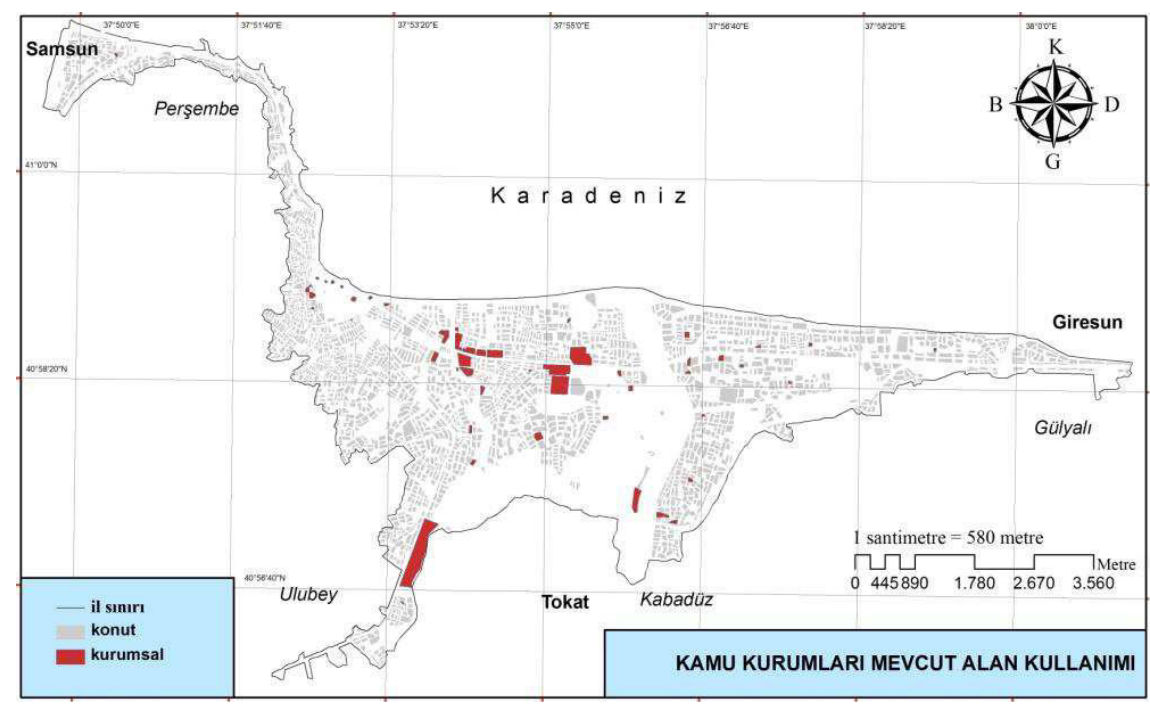

Şekil 7. Kamu kurumları mevcut alan kullanımları haritası 
Adnan Menderes University, Journal of Institute of Social Sciences, Vol.: 1, Special Issue

Kentteki ulaşım ağı dört temel gurupta incelenebilir. Bunlar; çevreyolu, bulvar, cadde ve sokaklardır. Çevreyolu kentin güneyinden, Turnasuyu, Akçatepe, Karapınar, Eskipazar ve Karacaömer mahallelerinden geçmekte olup, komşu illeri birbirine bağlayan bir transit yol özelliğindedir. Bulvar, Turnasuyu, Cumhuriyet, Karapınar, Durugöl, Karşıyaka, Akyazı, Bahçelievler, Yeni, Şarkiye, Düz, Taşbaşı, Kirazlimanı, Güzelyalı ve Kumbaşı mahallelerinden geçmekte olup hem kent içinde ana ulaşım arterini teşkil etmekte hem de komşu illerle bağlantı kuran yol özelliği taşımaktadır (Şekil 8).

Kentte ilköğretim okulları, liseler, eğitim merkezleri ve üniversite bulunmaktadır. Eğitim merkezi 1 adettir ve Karapınar Mahallesinde bulunmaktadır. İlköğretim okulları 73 adettir. Taşbaşı, Azizye ve Karapınar Mahalleleri dışında tüm mahallelerde ilköğretim okulu bulunmaktadır. Kentte 16 adet lise bulunmaktadır. Liseler Zaferimilli, Bucak, Şahincili, Yeni, Bahçelievler, Akyazı, Karapınar, Cumhuriyet, Akçtepe ve Turnasuyu Mahallelerinde bulunmakta olup. Eskiden yüksekokul olarak mevcut bulunan eğitim kurumu günümüzde üniversite olarak hizmet vermeye başlamış ve Ordu Üniversitesi adını almıştır. Ordu Üniversitesi ana kampüsü Cumhuriyet Mahallesinde bulunmak üzere, Güzelyalı, Bucak, Akyazı ve Akçatepe Mahallelerinde de yer almaktadır.

Kentteki sağlık kurum ve tesisleri hastaneler ve sağlık ocakları olmak üzere iki temel başlık altında toplanmaktadır. İmar planı verilerine göre kentte toplam 12 sağlık ocağ 1 ve 5 hastane bulunmaktadır. Hastaneler Bucak, Şahincili ve Akyazı Mahallelerinde yer almaktadır. Sağlık ocakları ise Kumbaşı, Selimiye, Akyazı, Karacaömer, Karapınar, Durugöl, Cumhuriyet, Akçatepe ve Turnasuyu Mahallelerinde bulunmaktadır. Ayrıca 2014 yılı itibariyle üniversiteye bağlı araştırma hastanesinin de yapımına başlanılacaktır.

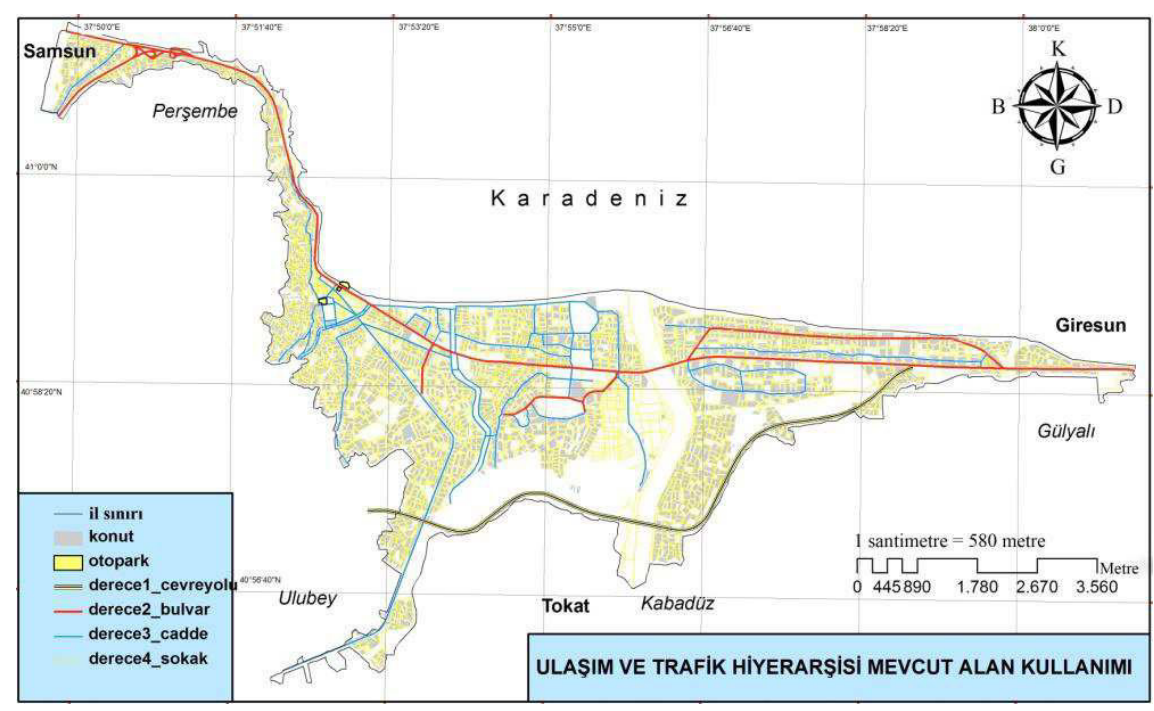

Şekil 8. Ulaşım ve trafik hiyerarşisi mevcut alan kullanımı haritası

\subsection{KENTSEL SORUNLAR}

Ordu'da kentleşmeye dair önemli olumsuz özellikler özellikle Karapınar Mahallesinde, ancak bunun dışında da küçüklü büyüklü olarak kentin farkı yerlerinde bulunan ve tamamen kent içerisinde kalmış olan sanayi tesisleridir. Bu tesisiler kentin değerli bir bölgesinde önemli ve büyük miktarlarda alanları kaplamaktadır.

Kentin içerisinden geçen ve halen transit taşımacılık ve ulaşım için de kullanılan karayolu da kent adına olumsuz özelliklerden birisidir. Kentin en önemli ulaşım arteri olup, kent içi ulaşımın da sağlandığı, ayrıca kentin en aktif kullanılan ve konut bölgelerinin yoğun olduğu yerleşim yerinin içinden geçen bu yol hem gürültü, görüntü ve hava kirliliğine neden olmakta, hem de trafik yoğunluğuna sebebiyet vermektedir. Ancak 
Adnan Menderes University, Journal of Institute of Social Sciences, Vol.: 1, Special Issue

başlanılan çevre yolu projesi ile bu sorunun çözülmesi hedeflenmekte, çevre yolunun tamamlanması ile transit taşımacılığın kent içinden çevre yoluna aktarılması planlanmaktadır. Bunun gerçekleşmesiyle birlikte kent çok önemli bir kent içi bulvar kazanmış olacaktır.

Kıyı kesimindeki plansız yapılaşma diğer önemli bir sorundur. Bu durum, kıyı kesiminin ve denizin uygun şartlarda ve etkin olarak kullanılamamasına neden olmaktadır. Yine de kent içinde kalan önemli bir bölüm yeşil alan ve plaj olarak değerlendirilebilmiştir.

1993 yılında çıkarılan ve daha sonra değişikliklere uğrayan ÇED yönetmeliğinden önce uygulamaya koyulan deniz dolgu sahaları diğer bir önemli başlıktır. Yeterli tahkimat yapılmadan bu alanlara boşaltılan hafriyat atıkları ve topraklar, suyun ve dalgaların etkisiyle denizde bulanıklığa sebep olmakta, deniz ekolojisini kötü yönde etkilemektedir. $\mathrm{Bu}$ yanlış uygulama aynı zamanda küçük balıkçı barınaklarının dolmasına neden olmaktadır (Ordu Valiliği Çevre ve Şehircilik Müdürlüğü, 2011).

İl genelinde iç kesimlerde bulunan köy nüfusun hızlı bir şekilde sahil kesimlerine göç etmesi ile de kent nüfusu artmakta, bu durum zaman içerisinde dağınık ve yoğun yerleşimlere neden olmakta, yetersiz alt yapıyla birleşince de kentsel sorunları tetiklemektedir.

Çöp depolama sahasının kent içerisinde kalmış olması da önemli bir diğer sorundur. Sorunun çözülmesi için yapılan çalışmalara karşın çöp döküm sahası artık kentin içerisinde kalan yerinde faaliyete devam etmektedir.

Trafik sorunu önemli bir diğer başlık olup, bunda alansal sorunlardan kaynaklanan kent yapılaşması büyük rol oynamaktadır. Dar yollar, kent içerisinden geçen karayolu ve otopark yetersizliği trafik sorununu artıran önemli etkenlerdir.

Artık tamamen kent içeresinde ve yerleşim yerleri arasında kalmış bulunan küçük ve organize sanayi ise hem kentleşmeyi, kentsel gelişimi olumsuz etkilemekte, hem kente estetik ve fonksiyonel yönden eksiler getirmekte, hem de gürültü, kirlilik ve yoğunluk açısından sorunlar doğurmaktadır.

Düzensiz kentleşme nedeniyle tetiklenen ve artış gösteren hava kirliliği ise kent sakinlerini önemli ölçüde olumsuz etkileyen bir diğer faktördür. Özellikle kent merkezi ve çevresinde dar ve düzensiz yapılaşmanın müsaade etmediği hava hareketleri nedeniyle kentsel kirlilik önemli oranda artış göstermekte ve hava koridorları ve hava sirkülasyonunun etkin şekilde sağlanamamış olmasından dolayı kirli hava kentten tahliye edilememektedir.

Özellikle kent merkezi ve çevresi yerleşimlerde yoğun kentsel yapılaşma nedeniyle estetik ve fonksiyonel başlıklarda kente olumsuz getiriler sağlamaktadır.

\subsection{KENTE YÖNELIK PLAN VE ÇALIŞMALAR}

2007 yılında onaylanan Çevre Düzeni Planı'nda merkez ilçenin (Altınordu) gelecek 15 yıllık kalkınması hususunda belirlenen başlıca sektörler tarım, sanayi, hizmetler ve turizm sektörleridir. Çevre Düzeni Planı kararları ise şöyledir;

-İlçe sınırlarında yoğun alan kaplayan fındık alanları, ilçenin gelişimi açısından önemli olup, bu ürünlerin artı değer getirmesi yönünde düzenlemelerin yapılması sağlanacaktır. Endüstriyel değeri yüksek olan findık üretiminin yoğunlaştığı ilçede tarımsal üretimin iktisadi girdisini artırmak için fındığın işlenmesi ve pazarlanması gerçekleştirilecektir.

-Kıyı ilçesi olması dolayısıyla balıkçılık geliştirilmesi kararlaştırılan tarım alt sektörlerinin başında gelmektedir. Belirlenen sanayi alanlarında balık üretiminde gerekli olan depolama alanları oluşturulması ve balık ürünlerine yönelik sanayinin teşvik edilmesi kararlaştırılmıştır.

- İlçenin zengin olan florası arıcılık sektörü ve bal üretiminin geliştirilmesi ile kırsal kalkınmaya katkı sağlaması öngörülmektedir. Kırsal alanda üretilen ve depolanan balın, ilçe merkezinde işlenerek pazara 
Adnan Menderes University, Journal of Institute of Social Sciences, Vol.: 1, Special Issue

sunulması sağlanacaktır. Kırsal alanda ön işleme, süzme gibi faaliyetlerin yapılacağı sektörün paketleme, pazarlama organizasyonu üretici birliklerinin etkin katılımıyla ilçe merkezinde gerçekleştirilecektir.

- Alt Bölge Merkezi olması dolayısıyla, üst ölçek kentsel donatıların bu ilçede yer seçmeleri öngörülmüştür. Ordu Çevre Yolu, Ordu-Mesudiye-Sivas Dereyolu, Ordu Merkez-Ulubey-Gürgentepe-Gölköy bağlantılarının kademesinin arttırılması ile ilçe merkezinin kuzey-güney ve doğu-batı akslarındaki insan, mal ve hizmet akışı güçlendirilmiştir.

- Ordu limanı, genel kullanımın yanı sıra kapasitesi geliştirilerek turizme yönelik yolcu taşımacılığı amaçlı düzenlenip, tasarlanacaktır.

- Karadeniz Bölgesini batı ile bağlayan birinci derece yolun üzerinde olması önemli bir potansiyel olmakla birlikte, bu önemli bağlantının demiryolu ile desteklenmesi ve özellikle sanayi açısından bölgenin gelişimi kararlaştırılmıştır.

- İlçe merkezi olması dolayısıyla, hizmet verdiği kırsal alanın ihtiyaç duyacağı temel eğitim ve sağlık donatıları oluşturulacaktır. Alt ölçekteki plan çalışmalarında buraların yer seçimi ve yapılaşma şartları belirlenecektir.

- Üretilen ürünlerin kırsal merkezlerde toplanması için gerekli depolama alanları sağlanacaktır. Kırsal kalkınma için oldukça önemli olan bu depolama alanlarının yer seçimi ve yapılaşma koşulları alt ölçekli planlarda belirlenecektir.

Ordu-Giresun İlleri "Turizmi Geliştirme Amaçlı Özel Proje Alanı" olarak ilan edilmiş, bu kapsamda Ordu Merkez İlçe, Gülyalı, Kabadüz, Mesudiye, Gölköy, Aybastı, Kabataş, Gürgentepe, Ulubey, Çamaş, Perşembe ve Fatsa İlçeleri ile Giresun'a bağlı 8 ilçede turizm amaçlı geliştirmelerin yapılması kararı alınmıştır. Çevre Düzeni Planı Raporuna göre; Ordu'da sahil kesiminde sahiller-kumsallar, deniz taşımacılığına dayalı turizm olanakları desteklenecek, iç kesimlere doğru gidildikçe, kültür turizmine ait unsurlar (kiliseler, kaleler, antik yerleşimler, kaya mezarları, müzeler, tarihi kentsel doku, anıt özelliğindeki eşi olmayan yapılar), ilin doğal yapısı, festivaller, akarsular, göller, geleneksel yayla kültürü ve evleri değerlendirilecek, Ordu Merkez ilçedeki limanın turizm amaçlı olarak kullanıma da hizmet verebilmesi için geliştirmeler planlanmaktadır" (Çevre Orman Bakanlığı, 2014).

Ayrıca Giresun'la ortak kullanılacak olan Ordu-Giresun Havalimanı'nın 2014 yılı içerisinde hizmete açılması planlanmaktadır. Havalimanın açılması kenti hem turizm, hem ticari, hem de üniversite bazında destekleyecek önemli bir unsur olacaktır.

\section{BÜYÜKȘEHİR OLMA SÜRECI}

1455 tarihli Osmanlı Tapu Tahrir Defterlerinde Ordu hakkında önemli bilgiler bulunmaktadır. Trabzon'dan 65 yıl önce Türk bölgesi haline gelen Ordu'da Türk olmayan (Rum ve Ermeni) etnik kökenlilerin oranı, Türk nüfusa göre çok düşük olarak belirtilmiştir. Gayri Türk olanların en yüksek olduğu 17. asır başlarında bile Türklere oranı sadece \%7,9'dur. Tapu Tahrir kayıtlarından, Ordu yöresinin Selçuklu dönemindeki idari teşkilatııın pek değiştirilmediği anlaşılmaktadır. 1520'de, bölgenin tamamı, Kaza-i Canik-i Bayramlu adıyla birleştirilmiş ve İskefsir, Bayramlu (Ordu), Bazarsuyu (Bulancak) olarak üç kazaya ayrılmıştır. 1548 yılında Ordu, Karahisar-Işarki (Giresun'un şimdiki ilçesi Şebinkarahisar) sancağına bağlıdır. 1869 yılında ilk Belediye Teşkilatı kurulmuştur. Trabzon Mutasarrıflığının yazısına göre, Bucak (Ordu) Belediyesinin ilk başkanı Hasan Ağa'dır. 1920 tarihinde Ordu kazasının 6 nahiyesi, 318 köyü ve 180 bin nüfusu vardı. Yani Trabzon vilayetinin en gelişmiş kaza merkeziydi. 4 Aralık 1920 tarihinde "Müstakil Sancak" yapıldı. Bu karar 69 Sayılı yasayla 4 Nisan1921 tarihinde yürürlüğe girerek il statüsüne kavuşmuştur (Türkiye İstatistik Kurumu, 2012).

Büyükşehir belediyesi olgusu, 1984 yılında uygulamaya girmiş, üst kademe belediyecilik anlayışıdır. $\mathrm{Bu}$ tarihte Ankara, İstanbul ve İzmir Büyükşehir Belediyeleri olarak Türkiye'nin en kalabalık nüfusa sahip kentlerinde başlamış olup, başlangıçta sadece kent bazında uygulaması bulunan, merkez ilçede kurulan belediyelerin üst belediyesi konumunda ve il bazındaki ilçe belediyelerin mevcut sistemleriyle işlediği bir 
Adnan Menderes University, Journal of Institute of Social Sciences, Vol.: 1, Special Issue

sistemdir. Bu belediyeler 1982 Anayasasının 127. Maddesindeki "Büyük yerleşim yerlerinde özel yönetim biçimleri oluşturulabilir" hükmüne dayanılarak kurulmuştur.

2004 yılında çıkarılan 5216 sayılı yasayla, büyükşehir belediye sınırları için yeni kıstaslar getirilmiştir. Buna göre, büyükşehir olma koşulu nüfusun en az 750.000 olmalıdır. Aynı yasa nüfus yoğunluğu çok yüksek olan İstanbul ve Kocaeli (İzmit) İllerinin tamamını büyükşehir sınırları içerisine almaktadır. Diğer büyükşehirlerin sınırları için coğrafi ölçüm şartı getirilmiştir. Buna göre il sınırları içinde olmak ve valilik binası merkez alınmak suretiyle,

- Nüfusu 2.000.000'dan fazla olan büyükşehirlerde $50 \mathrm{~km}$ yarıçapındaki yerleşim yerleri,

- Nüfusu 1.000 .000 - 2.000.000 arası olan büyükşehirlerde $30 \mathrm{~km}$ yarıçapındaki yerleşim yerleri,

- Nüfusu 1.000 .000 'dan az olan büyükşehirlerde ise $20 \mathrm{~km}$ yarıçapındaki yerleşim yerleri büyükşehire dahil edilmiştir.

- Daha sonra 2012 y1lındaki değişiklikler ile kanun güncel halini almıştır.

23.07.2004 Tarih ve 25531 say1lı Resmi Gazete'de yayınlanan 10.07.2004 kabul tarih ve 5216 kanun numaralı "Büyükşehir Belediyesi Kanunu"nun ikinci bölümünde "Büyükşehir Belediyesinin Kuruluşu ve Sınırları", "Kuruluş" başlığı altındaki Madde 4 ve " Büyükşehir Belediyesinin Sınırları başlığı altındaki Madde 5 aşağıdaki gibi değiştirilmiştir;

"Madde 4-(Değişik: 12/11/2012-6360/5 md.) ${ }^{(4):}$ Toplam nüfusu 750.000'den fazla olan illerin il belediyeleri kanunla büyükşehir belediyesine dönüştürülebilir.

Büyükşehir belediyesinin stnırları, Madde 5-(Değişik: 12/11/2012-6360/6 md.) ${ }^{(5):}$ Büyükşehir belediyelerinin sınırları, il mülki sınırlarıdır. İlçe belediyelerinin sınırları, bu ilçelerin mülki sınırlarıdır" (Mevzuatı Geliştirme ve Yayın Genel Müdürlüğü, 2014).

Bu kanun ile büyükşehir belediyeleri için il mülki sınırları belediye sınırı kabul edildiğinden büyükşehir belediyeleri için il nüfusları önemli ve belirleyici hale gelmiştir. Türkiye İstatistik Kurumu'nun (TÜIK) açıkladığı 2011 yılına ilişkin "Adrese Dayalı Nüfus Kayıt Sistemi Sonuçları" dikkate alınmış ve 12 Kasım 2012 tarihi itibarnyla Büyükşehir yasa tasarısı, Meclis Genel Kurulu'nda kabul edilerek 6360 sayılı kanun olarak yasalaşmıştır. Büyükşehir olan iller ve nüfusları ise şöyledir (Wikipedia, 2014);

Şanlıurfa: 1.762 .075

Hatay: 1.483 .674

Manisa: 1.346.162

Balıkesir: 1.160 .731

Kahramanmaraş: 1.063.174

$\begin{array}{ll}\text { Van: } 1.051 .975 & \text { Mardin: } 773.026 \\ \text { Aydın: } 1.006 .541 & \text { Malatya: } 762.366 \\ \text { Denizli: } 950.557 & \text { Trabzon: } 757.898 \\ \text { Tekirdağ: } 852.321 & \text { Ordu: } 771.960 \\ \text { Muğla: } 851.145 & \end{array}$

Ordu'nun büyükşehir belediyesi olma süreci bu anlamda farklı gelişmiştir. 2012 y1lında, 16 büyükşehir belediyesine ilaveten 13 büyükşehir belediyesinin kurulmasına yönelik bir kanun çıkarılmıştır. Bu kanun ilk çıktığı haliyle 13 büyükşehir ve 26 ilçe kurulmasını kapsamaktayken, 2013 yılında kanunda değişiklik yapılarak 14 büyükşehir ve 27 ilçe kurulması haline dönüştürülmüştür. Bu haliyle 14. Büyükşehir belediyesi olarak Ordu, ilçe olarak da Altınordu kurulmuştur.

22.03.2013 Tarih ve 28595 say1l1 Resmi Gazete'de yayınlanan 14/3/2013 kabul tarihli ve 6447 kanun numaralı "On Üç İlde Büyükşehir Belediyesi ve Yirmi Altı İlçe Kurulması ile Bazı Kanun ve Kanun Hükmünde Kararnamelerde Değişiklik Yapılmasına Dair Kanunda Değişiklik Yapılması Hakkında Kanun"da Ordu Büyükşehir Belediyesi ile ilgili karar aşağıdaki gibidir; 
Adnan Menderes University, Journal of Institute of Social Sciences, Vol.: 1, Special Issue

"Madde 1 - (1) 12/11/2012 tarihli ve 6360 sayılı On Üç İlde Büyükşehir Belediyesi ve Yirmi Altı İlçe Kurulması ile Bazı Kanun ve Kanun Hükmünde Kararnamelerde Değişiklik Yapılmasına Dair Kanunun başlı̆gında yer alan "ON ÜÇ" ibaresi "ON DÖRT" olarak, "YİRMİ ALTI" ibaresi "YİRMİ YEDİ" olarak değiştirilmiş ve 1 inci maddesinin birinci fikrasında yer alan "Muğla," ibaresinden sonra gelmek üzere "Ordu," ibaresi eklenmiştir.

(2) 6360 sayılı Kanunun 2 nci maddesinin yirmiüçüncü fikrasından sonra gelmek üzere aşağıdaki fikra eklenmiş ve diğer fikralar buna göre teselsül ettirilmiştir.

“(24) Ordu ilinde, Ordu Belediyesinin mahalleleri merkez olmak üzere, Ordu Merkez ilçe sınırları içerisindeki köyler ile belediyelerden oluşan Altınordu ilçesi ve aynı adla belediye kurulmuştur."

(3) 6360 sayılı Kanunun geçici 1 inci maddesinin onyedinci fikrasına bağlı ekli (25) sayılı listeye "AltınorduBelediyesi" ibaresi ile maddeye aşağıdaki fikra eklenmiş ve yirmibirinci fikrasında yer alan "26 adet" ibaresi "27 adet” ş̧eklinde değiştirilmiştir" (Resmi Gazete, 2014).

06/12/2012 Tarih ve 28489 sayılı Resmi Gazete'de yayınlanan 12/11/2012 kabul tarihli ve 6360 kanun numaralı "On Dört İlde Büyükşehir Belediyesi ve Yirmi Yedi İlçe Kurulması ile Bazı Kanun ve Kanun Hükmünde Kararnamelerde Değişiklik Yapılmasına Dair Kanun"da büyükşehir belediyelerinin ve ilçelerin kurulması ve sınırları ile ilişkili kısım şöyledir;

\section{"Büyükşehir belediyesi kurulması ve sınırlarının belirlenmesi}

Madde 1 - (1) Aydın, Balıkesir, Denizli, Hatay, Malatya, Manisa, Kahramanmaraş, Mardin, Muğla, Ordu, Tekirdağ, Trabzon, Şanlıurfa ve Van illerinde, sınırları il mülki sınırları olmak üzere aynı adla büyükşsehir belediyesi kurulmuş ve bu illerin il belediyeleri büyükşehir belediyesine dönüştürülmüştür.

(2) Adana, Ankara, Antalya, Bursa, Diyarbakır, Eskişehir, Erzurum, Gaziantep, İzmir, Kayseri, Konya, Mersin, Sakarya ve Samsun büyükşehir belediyelerinin sınırları il mülki sınırlarıdır.

(3) Birinci ve ikinci fikrada sayılan illere bağlı ilçelerin mülki sınırları içerisinde yer alan köy ve belde belediyelerinin tüzel kişiliği kaldırılmış, köyler mahalle olarak, belediyeler ise belde ismiyle tek mahalle olarak bağlı bulundukları ilçenin belediyesine katılmıştır.

(4) İstanbul ve Kocaeli il mülki sınırları içerisinde bulunan köylerin tüzel kişiliği kaldırılarak bağlı bulundukları ilçe belediyesine mahalle olarak katılmıştır.

(5) Birinci, ikinci ve dördüncü fikrada sayılan illerdeki il özel idarelerinin tüzel kişiliği kaldırılmıştır.

(6) Birinci ve ikinci fıkrada sayılan illerin bucakları ve bucak teşkilatları kaldırılmıştır.

\section{İlçe kurulması ve sınırlarının belirlenmesi}

Madde 2 -(24) (Ek: 14/3/2013-6447/1 md.) Ordu ilinde, Ordu Belediyesinin mahalleleri merkez olmak üzere, Ordu Merkez ilçe sınırları içerisindeki köyler ile belediyelerden oluşan Altınordu ilçesi ve aynı adla belediye kurulmuştur. ${ }^{(1)}$

(1) 14/3/2013 tarihli ve 6447 sayılı Kanunun 1 inci maddesiyle, 2 nci maddenin yirmi üçüncü fikrasından sonra gelmek üzere bu fikra eklenmiş ve diğer fikralar buna göre teselsül ettirilmiştir.

\section{(25) Sayılı Liste ${ }^{(1)}$}

\begin{tabular}{llll}
1 & Altıeylül Belediyesi & 15 & Karesi Belediyesi \\
\hline 2 & Antakya Belediyesi & 16 & Menteşe Belediyesi \\
\hline 3 & Arsuz Belediyesi & 17 & Merkezefendi Belediyesi \\
\hline 4 & Artuklu Belediyesi & 18 & Onikişubat Belediyesi
\end{tabular}


Adnan Menderes University, Journal of Institute of Social Sciences, Vol.: 1, Special Issue

\begin{tabular}{llll}
5 & Battalgazi Belediyesi & 19 & Pamukkale (Akköy) Belediyesi \\
\hline 6 & Defne Belediyesi & 20 & Payas Belediyesi \\
\hline 7 & Dulkadiroğlu Belediyesi & 21 & Seydikemer Belediyesi \\
\hline 8 & Efeler Belediyesi & 22 & Süleymanpaşa Belediyesi \\
\hline 9 & Ergene Belediyesi & 23 & Şehzadeler Belediyesi \\
\hline 10 & Eyyübiye Belediyesi & 24 & Tuşba Belediyesi \\
\hline 11 & Haliliye Belediyesi & 25 & Ortahisar Belediyesi \\
\hline 12 & İpekyolu Belediyesi & 26 & Yeşilyurt Belediyesi \\
\hline 13 & Kapaklı Belediyesi & 27 & Yunusemre Belediyesi \\
\hline 14 & Karaköprü Belediyesi & 28 & Altınordu Belediyesi \\
\hline
\end{tabular}

(1) 14/3/2013 tarihli ve 6447 sayll Kanunun 1 inci maddesiyle bu listeye "Altınordu Belediyesi" ibaresi eklenmiştir"(Resmi Gazete, 2014).

Ordu İli'nde büyükşehir belediyesi süreci öncesinde merkez ilçeler dahil 19 ilçe, 72 belediye ve 481 köy bulunmaktadır (Türkiye İstatistik Kurumu, 2012). Büyükşehir statüsüne geçilmesi ile birlikte belde belediyeleri kapatılmıştır. Tüzel kişilikleri kaldırılan belediye ve köylerin personeli, her türlü taşınır ve taşınmaz malları, hak, alacak ve borçları, komisyon kararıyla ilgisine göre bakanlıklara, büyükşehir belediyesi, bağl1 kuruluşu veya ilçe belediyesine devredilmiştir. Bütün bu işlemleri; Ordu Valiliği’nce oluşturulacak bir komisyon yürütmektedir. Devir işlemleri ilk mahalli idareler genel seçimi itibarıyla uygulamaya konulmuştur. Ordu'daki köyler ve beldeler bağlı bulundukları ilçenin mahallesine dönüşmüşlerdir. $\mathrm{Bu}$ köyler ve beldeleri ilçe merkezlerine bağlayan yolların yapılması, bu yolların bakım ve onarımı, temizliği ve karla mücadele çalışmasını Ordu Büyükşehir Belediyesi yürütecektir. Büyükşehir belediyesi tarafından yürütülecek diğer başlıca hizmetler de şöyle sıralanabilir;

- İtfaiye hizmetleri ilin tamamında Ordu Büyükşsehir belediyesince verilecek, buna göre bütün il genelinde teşkilatlanacak ve uygun yerlerde birimleri konuşlanacaktır.

- Su ve kanalizasyon hizmetleri Ordu Büyükşsehir Belediyesince verilecek ve buna göre; bütün il genelinde teşkilatlanacak ve uygun yerlerde birimleri konuşlanacaktır.

- Kara, deniz, su ve demiryolu üzerinde işletilen her türlü servis ve toplu ulaşım hizmetleri Ordu Büyükşehir Belediyesince planlanacak ve işletilecektir.

- Toptancı halleri (Su Ürünleri, Yaş Sebze Meyve Halleri) ve mezbahaneler Ordu Büyükşehir Belediyesince yapılacak ve işletilecektir.

- Yolcu ve yük terminalleri, kapalı ve açık otoparklar yapmak, yaptırmak, işletmek, işlettirmek veya ruhsat vermek Ordu Büyükşehir Belediyesinin görevi olacaktır.

- Çevrenin, tarım alanlarının ve su havzalarının korunmasını sağlamak; ağaçlandırma yapmak; hafriyat toprağı, moloz, kum ve çakıl depolama alanlarını, odun ve kömür satış ve depolama sahalarını belirlemek Ordu Büyükşehir belediyesince yapılacaktır.

- Katı atık yönetimi, depolanması ve bertaraf edilmesine ilişkin hizmetler Ordu Büyükşsehir Belediyesince yapılacaktır.

- Mezarlık alanlarını tespit etmek, mezarlıklar tesis etmek, işletmek, işlettirmek, defin ile ilgili hizmetleri yürütmek.

- Zabita Hizmetleri vermek (Haber Ordu, 2014). 


\section{SONUÇ}

Ordu Kenti eski ancak büyük olmayan bir yerleşimdir. Zamanla, özellikle kent merkezi ve çevresi eski yerleşim düzeninden ve coğrafi kısıtlamalar nedeniyle oldukça sıkışık ve yoğun bir hal almıştır. Kentte mevcut sorunlara rağmen Ordu huzurlu, sakin ve doğal kaynaklar bakımından zengin yapısı ve yüksek potansiyeliyle çekici özelliği olan, çevre kentler için günü birlik dinlence ve rekreasyon imkanı tanıyan önemli bir ildir.

Kent bir gelişme ve değişim sürecinde olmasına rağmen, bu hızlı seyretmeyen bir süreçtir. Tabi ki Ordu gibi doğal kaynaklar, rekreasyonel, turistik, kültürel ve sosyal aktiviteler bakımından zengin, ancak bir o kadar da sakin kent ve ilçeleri ile yapılaşma ve kentsel büyümenin hızlı seyretmiyor oluşu bir şans olarak kabul edilmelidir. Objektif bir bakış açısıyla kentin büyük olmayan ve çok gelişmemiş yapısı doğal kaynaklarının devamlılığını sağlamış ve korumuştur.

Ancak üniversite, havaalanı, büyükşehir statüsü gibi olgular kentin gelişim ve dönüşümüne ivme kazandıracak, nüfusun artmasını sağlayıcı etkide bulunacaktır. Bu da uzun vadede küçük, sahil kenti ve sahil ilçeleri yapısından, gelişmiş, genişlemiş, sempatisini ve sadeliğini kaybetmiş bir büyük şehre dönüşümüne neden olacaktır.

1984 y1lından günümüze kadar Türkiye'de 30 büyükşehir belediyesi kurulmuştur. Büyükşehir belediyesi artık belirli bir nüfus büyüklügüne ulaşmış kentler için yönetimsel kolaylık ve ulaşılabilirlik sağlama amacı ile ortaya çıkan bir olgudur. Aynı zamanda Türkiye için zorunluluk mudur, gereklilik midir, ihtiyaç mıdır boyutunda tartışılan da bir olgudur. Büyükşehir ilan edilme sürecindeki tek kriter nüfus mu olmalıdır, daha başka kriterler de aranmalı mıdır? sorusunun değerlendirilmesi gerekir. Kentler de insanlar gibi basamakları birer birer çıkmalı, erkenden yorulmamalı, her aşamayı sindire sindire, bir üst basamak için gerek ve şartları sağladıktan sonra basamak atlamalıdırlar. Hızlı adımlar aceleci ve erken olabilir. Kentler için hızlı ve aceleci gelişmeler düzensiz ve özensiz kentler doğurur ve kentler için geri dönüşü çoğu zaman çok zor, bazen de imkansız olabilen sonuçlara sebebiyet verir. Esas olan günceli takip ederek, çağın gerekleri, kent sakinlerinin talep ve gerekliliklerini estetik ve fonksiyonelliğgi göz önünde bulundurarak, doğal, tarihi ve kültürel değerlerini muhafaza ederek, sadece günü değil geleceği hatta uzak geleceğin şart ve gereksinimlerini de hesap ederek, süreklilik ve yaşanabilirlik ilkeleri çerçevesinde kentleri planlamak ve tasarlamaktır.

Son yıllarda, AB'ye uyum çerçevesinde, yerel yönetimlere ilişkin getirilen yeni düzenlemeler ve geliştirilen yeni standartlar nispeten büyük ve orta ölçekli kentlerin planlama ve yönetiminde etki alanı ile birlikte ele alınması yolunda birtakım çabaları içerse de, henüz istenilen düzeyde sağlıklı bir yapılanmanın yolunu açtı̆̆ını söylemek mümkün değildir (K1lıç 2010).

$\mathrm{Bu}$ süreçte en yeni büyükşehir belediyesi olan Ordu bu evreyi en hızlı yaşayan ildir. Büyükşehir belediyesi statüsüne geçmesiyle Ordu İli'ne ne getirilerinin olacağı ancak bu aşamadan sonra belirginleşecektir. 


\section{KAYNAKÇA}

ALTAY, D.,TOKMAN, L., Y., TANRIKULU, A., (2009), "Kentli Hakları El Kitab1 (Avrupa Kentsel Şart1)",http://www.unfpa.org.tr/turkey/rapyay/kentlihaklari.pdf, (Erişim Tarihi 21.03.2014)

ATABEYOĞLU, Ö., TURGUT, H., ERDOĞAN, A., (2010), "Selçuklu Sonrası Anadolu Türk Kültüründe Yeşil Alanların Kentleşmedeki Yeri", Peyzaj Mimarlığı IV. Kongresi, 21-24 Ekim, İzmir.

ATABEYOĞLU, Ö.,(2011), "Ordu Kenti Yapısal Peyzaj Karakter Analizi ve Kentsel Planlama Stratejileri", Atatürk Üniversitesi Fen Bilimleri Enstitüsü, Yüksek Lisans Tezi, 204s, Erzurum.

AYDEMIR, Ş.,(1999), "Kentsel Alanların Planlanması ve Tasarımı", Karadeniz Teknik Üniversitesi Mühendislik Mimarlık Fakültesi Ders Notları, No: 54, Trabzon.

ERGEN, Y., B., (1981),"Şehircilik", Yüksek Teknik Öğretmen Okulu Matbaası, Ankara.

GÜÇLÜ, Ö.,(1993), "İstanbul'un Kentsel Kimliği ve Değişimi", İstanbul, İ.T.Ü. - Fen Bilimleri Ens. Y.L Tezi, s.34.

Haber Ordu (2014),"Tüm Yönleriyle Büyükşehir", http://www.haberordu.com/tum-yonleriyle-buyuksehir18133h.htm, (Erişim tarihi: 10.03.2014)

KELEŞ, R.,(1990),"Kentleşme Politikası", İmge Yay., Ankara,.

KILINÇ, G.,(2010),"Çeyrek Asırlık Bir Tecrübe: Türkiye'de Büyükşehir Belediyelerinin Yapılanması ve Kayseri Büyükşsehir Belediyesi Örneği”, Çağdaş Yerel Yönetimler, Cilt 19 Sayı 1, s.67-89.

TC Başbakanlık Mevzuatı Geliştirme ve Yayın Genel Müdürlügü(2014),"Büyükşehir Belediyesi Kanunu", www.mevzuat.gov.tr/MevzuatMetin/1.5.5216.doc,(Erişim tarihi; 21.03.2014)

TC. Çevre ve Orman Bakanlığ (2006),"Ordu, Trabzon, Rize, Giresun, Gümüşhane, Artvin Planlama Bölgesi Çevre Düzeni Planı", Ankara.

TC Çevre ve Orman Bakanlığı (2014),"Ordu, Trabzon, Rize, Giresun, Gümüşhane, Artvin Planlama Bölgesi 1/100.000 Ölçekli Çevre Düzeni Planı Plan Açıklama Raporu", Ankara.

http://www.csb.gov.tr/gm/mpgm/index.php?Sayfa=sayfaicerik\&IcId=495,(Erişim tarihi; 20.03.2014)

TC Ordu Valiliği Çevre ve Şehircilik Müdürlüğü (2011), "Ordu Çevre Durum Raporu", Ordu.

TC Resmi Gazete (2014), http://www.resmigazete.gov.tr

Türkiye İstatistik Kurumu (2012),"Seçilmiş Göstergelerle Ordu", Yayın No: 4083, Ankara.

TC Ordu Valiliği İl Çevre ve Orman Müdürlüğü(2004),"Ordu Çevre Durum Raporu", s194, Ordu.

Türkiye İstatistik Kurumu (2014), "Temel İstatistikler", www.tuik.gov.tr, (Erişim tarihi: 10.03.2014)

Wikipedia(2014),"Türkiye'de Büyük Şehir Belediyeleri",

http://tr.wikipedia.org/wiki/T\%C3\%BCrkiye'de_b\%C3\%BCy\%C3\%BCk\%C5\%9Fehir_belediyeleri, (Erişim tarihi: 10.03.2014) 